\title{
Characterisation of atypical Aeromonas salmonicida infection in Arctic charr Salvelinus alpinus and European grayling Thymallus thymallus
}

\author{
Päivi Pylkkö ${ }^{1,2}$, Tarja Pohjanvirta ${ }^{1}$, Jari Madetoja ${ }^{1,3}$, Sinikka Pelkonen ${ }^{1, *}$ \\ ${ }^{1}$ National Veterinary and Food Research Institute, Kuopio Department, PO Box 92, 70701 Kuopio, Finland \\ ${ }^{2}$ University of Jyväskylä, Department of Biological and Environmental Sciences, PO Box 35, 40351 Jyväskylä, Finland \\ ${ }^{3}$ Laboratory of Aquatic Pathobiology, Department of Biology, Åbo Akademi University, BioCity, Artillerigatan 6, 20520 Åbo, Finland
}

\begin{abstract}
Cultured stocks of Arctic charr Salvelinus alpinus and European grayling Thymallus thymallus are vulnerable to infection by achromogenic atypical Aeromonas salmonicida (AAS). In Finland, natural stocks of both fish species have to be supported by restocking, and AAS infection poses a threat to successful restocking because no preventive means are available. In this study, we analysed AAS isolates from Arctic charr and European grayling and from other sources genetically, and characterised the signs and pathology of AAS infection in Arctic charr and European grayling both under farming conditions and after experimental challenge. AAS outbreaks were recorded in 1 fish farm over an 8 yr period. Among various salmonid fishes under farming conditions, only Arctic charr and European grayling were susceptible to AAS infection. The disease caused by AAS could be reproduced in both species using the same AAS strain in an experimental challenge. The course of the disease and pathology of natural and experimental AAS infection differed between the 2 species, even though only 1 strain was used for challenge. Isolates of AAS from Arctic charr and European grayling were genetically identical within a single river water basin. However, genetic heterogeneity was observed among the isolates from different water basins. In both species, AAS caused systemic infection. The results suggest that the same AAS strain could be used to develop a vaccine to protect both Arctic charr and European grayling from AAS infection.
\end{abstract}

KEY WORDS: Atypical Aeromonas salmonicida - Arctic charr - European grayling $\cdot$ Experimental challenge $\cdot$ Pathology $\cdot$ Pulsed-field gel electrophoresis

Resale or republication not permitted without written consent of the publisher

\section{INTRODUCTION}

Various types of atypical Aeromonas salmonicida (AAS) cause disease in wild and cultured fish species worldwide (Rintamäki \& Valtonen 1991, Austin \& Austin 1993, Gudmundsdóttir 1997, Wiklund \& Dalsgaard 1998). In Finland, the infection severely affects cultured stocks of Arctic charr Salvelinus alpinus and European grayling Thymallus thymallus (hereafter referred to as charr and grayling, respectively). Mortality can be high, and all age groups are affected. The infection in charr and grayling is typically systemic in its severe form, and the pathogen can be isolated from the kidney and skin lesions of the fish (Carlstein 1996, Hänninen \& Hirvelä-Koski 1999). However, field cases have shown differences in the course and pathology of the disease.

Current taxonomy of Aeromonas salmonicida includes 5 subspecies: salmonicida, achromogenes, smithia, masoucida (Holt et al. 1994) and pectinolytica (Pavan et al. 2000). The AAS strains encompass the subspecies other than salmonicida, but according to their molecular and phenotypic characteristics, many AAS strains do not fit well into any of the subspecies (Austin et al. 1998). Studies of AAS strains isolated from different host species have shown that certain AAS types may be associated with specific fish species. The isolates analysed from Finnish charr and grayling have been assigned to certain ribotypes and XbaImacrorestriction profiles (Hänninen \& Hirvelä-Koski 
1999) that are generally achromogenic (Hänninen \& Hirvelä-Koski 1997, 1999, Madetoja et al. 2003).

The pathogenic mechanism of AAS infection in charr and grayling remains unresolved. Extracellular products do not seem to play a major role as virulence determinants (Madetoja et al. 2003). This finding was recently supported by Gudmundsdóttir et al. (2003), who classified the analysed Finnish strains as nontoxic according to their exotoxin secretion. Furthermore, earlier, Austin et al. (1998) observed no caseinase production and very poor gelatinase production by the AAS isolate originating from Finnish grayling. In this respect the pathogenesis of AAS infection in charr and grayling differs from the AAS infection in Atlantic salmon Salmo salar in Iceland and from furunculosis caused by typical A. salmonicida subsp. salmonicida.

This study was undertaken to learn more about the AAS infection in charr and grayling. We wanted to determine whether the same AAS strains infect both fish species on fish farms, and if the different course of disease caused by AAS observed in charr and grayling depends on bacterial or fish host factors. For this purpose, AAS isolates from various sources were analysed genetically, and the disease was reproduced experimentally in charr and grayling using a single AAS strain. The particular susceptibility of these fish species to infection was analysed by collecting retrospective data on the occurrence of the disease on a fish farm with multiple fish species in culture.

\section{MATERIALS AND METHODS}

Outbreaks on a fish farm. All data from AAS outbreaks recorded in 1990 to 1998 on Fish Farm A from the River Vuoksi water basin were analysed. Fish health status had been recorded daily, and the records included information on AAS outbreaks, signs of the disease, fish species affected, mortality, time of outbreak and medication. Fish samples from each outbreak had been sent for diagnosis to the National Veterinary and Food Research Institute (EELA), Kuopio. Diagnostic documents recording gross pathology, histopathology and microbiology were also available.

AAS isolates. Altogether, 36 atypical achromogenic and 1 pigment-producing (Strain 202) Aeromonas salmonicida isolates from Finland from different water basins, collected during the years 1988 to 1995, were analysed (see Table 1). The biochemical characteristics and extracellular products of the isolates have been described by Madetoja et al. (2003). The isolates originated from 11 fish farms and wild fishes and were from various fish species: 7 isolates were from charr and 15 isolates from grayling, and these had been isolated either from kidney, spleen or skin lesions; 21 isolates were from the River Vuoksi water basin from the years 1989 to 1995 and 11 isolates from the River Kymijoki water basin from the years 1988 to 1995; 8 isolates from farmed and wild salmonid fishes from Sweden were also included (Swedish Veterinary Institute, SVA, Uppsala) (see Table 1). The ATCC 33659 isolate served as a reference strain for AAS.

The isolates were stored at $-70^{\circ} \mathrm{C}$ before use. They were cultured in brain/heart infusion broth (BHI, Difco) or on trypticase soy agar (TS agar, Difco) with $5 \%$ defibrinated bovine blood. Cultures were incubated at $20^{\circ} \mathrm{C}$ for 2 to $3 \mathrm{~d}$.

Challenge experiment. We used 20 charr (1 yr old, mean weight $49.8 \pm 4.8 \mathrm{~g}$ ) and 43 grayling (1 yr old, mean weight $22.1 \pm 8.5 \mathrm{~g}$ ) from Fish Farm A in a challenge experiment. The fishes were held at ambient water temperature $\left(0.5\right.$ to $\left.3^{\circ} \mathrm{C}\right)$ until transfer to the EELA for the challenge experiment. The fishes were kept in $140 \mathrm{l}$ fibreglass tanks with aerated continuous flow-through ozonated lake water, with the charr and grayling in separate tanks. The control fish were handled and distributed similarly. The rearing density was adjusted to $8 \mathrm{~kg} \mathrm{~m}^{-3}$ in all tanks. The inflow water temperature was raised over a period of $7 \mathrm{~d}$ from 3 to $12^{\circ} \mathrm{C}$ and thereafter by $1^{\circ} \mathrm{C} \mathrm{d}^{-1}$ up to $16^{\circ} \mathrm{C}$, and was then kept constant at $16 \pm 0.5^{\circ} \mathrm{C}$. The fishes were fed daily with commercial food pellets. Experimental infection was carried out under License No. 191097295170 granted by the County Government of Kuopio, Finland.

AAS Strain No. 9 (Austin et al. 1998, Madetoja et al. 2003) was cultured in TS broth (Difco) at $20^{\circ} \mathrm{C}$ on an orbital shaker for $22 \mathrm{~h}$. For exposure, fresh bacterial culture in the TS broth was suspended in $11 \mathrm{l}$ of sterilised lake water $\left(15^{\circ} \mathrm{C}\right)$ to obtain $10^{7}$ colony forming units (CFU) $\mathrm{ml}^{-1}$ AAS bacteria, determined by counting on agar plates. The fishes were transferred to the challenge tanks for a $10 \mathrm{~min}$ bath exposure. Charr and grayling were exposed at the same time. Control fishes (2 tanks) were similarly bath exposed, but the lake water contained sterile TS broth instead of AAS culture. The challenged fishes were observed for $21 \mathrm{~d}$.

Each fish that was moribund or exhibited abnormal swimming behaviour was killed by a blow to the head and exsanguination, dissected and tissue samples from skin, muscle, intestine, kidney, spleen, liver and heart were taken for histopathological and microbiological examination. Organs were fixed in phosphate buffered $4 \%$ formaldehyde and subsequently embedded in paraffin; sections were stained with haematoxylineosin and Gram stain. Samples from the kidney and intestine were cultured on blood agar. The inoculated plates were incubated at $20^{\circ} \mathrm{C}$ for $7 \mathrm{~d}$.

Pulsed-field gel electrophoresis (PFGE). Isolates were grown on blood agar at $20^{\circ} \mathrm{C}$ for $3 \mathrm{~d}$. Colonies were transferred into $2 \mathrm{ml}$ of $1 \mathrm{M} \mathrm{NaCl}, 10 \mathrm{mM}$ Tris 
(pH 7.5), 0.1 M EDTA, and bacterial cells were pelleted down $\left(400 \times g, 10 \mathrm{~min},+4^{\circ} \mathrm{C}\right)$ and washed once with the buffer. Cells were resuspended in $0.5 \mathrm{ml}$ buffer, mixed with an equal volume of $1.4 \%$ InCert agarose (BMA), and the mixture was pipetted into gel blocks. The plugs were placed into lysis solution (10 mM Tris, $\mathrm{pH} 7.5,50 \mathrm{mM} \mathrm{NaCl}, 0.1$ EDTA, $0.2 \%$ sodiumdeoxycholate [w/v], $2 \mathrm{mg} \mathrm{ml}^{-1}$ lysozyme) and incubated at $37^{\circ} \mathrm{C}$ for $20 \mathrm{~h}$ followed by treatment with Proteinase $\mathrm{K}$ $\left(1.0 \mathrm{mg} \mathrm{ml}^{-1}\right)$ in $0.5 \mathrm{M}^{2}$ EDTA, $1 \%$ (w/v) N-lauroylsarcosine at $50^{\circ} \mathrm{C}$ for $1 \mathrm{~d}$. Slices of the plugs were incubated in $10 \mathrm{mM}$ Tris, pH 7.5, $1 \mathrm{mM}$ EDTA, $50 \mathrm{mM} \mathrm{NaCl}$ for $2 \mathrm{~d}$, and then digested with restriction enzymes. Plugs were digested overnight with $20 \mathrm{U}$ of SpeI (New England Biolabs). Restriction enzymes NotI, SfiI, SmaI and $\mathrm{XbaI}$ were also tested, but these digested the genome into so many small fragments that it was not possible to interpret the gels.

Electrophoresis was performed in a Bio-Rad CHEF DRIII apparatus in $0.5 \times \mathrm{TBE}(45 \mathrm{mM}$ Tris-borate and $0.5 \mathrm{mM}$ EDTA $\mathrm{pH}$ 8.0) through $1 \%$ pulsed-field agarose (Bio-Rad) at $14^{\circ} \mathrm{C}$. A linear pulse ramp from 2.5 to $25 \mathrm{~s}$ was used. Running time was $18 \mathrm{~h}$, angle $120^{\circ}$ and voltage $6 \mathrm{~V} \mathrm{~cm}^{-1}$. Gels were stained with ethidium bromide, de-stained with distilled water, and photographed under UV light.

Spel produced 20 to 30 fragments of molecular sizes of approximately 20 to $400 \mathrm{~kb}$. Macrorestriction profiles (MRP) were analysed visually. Isolates were grouped as MRP 1 if they had 3 heavy bands in SpeI MRP (approximately 280 to $390 \mathrm{~kb}$ ) and to MRP 2 if they had 2 heavy bands (approx. 310 to $430 \mathrm{~kb}$ ). When MRPs differed even by 1 band from each other within the main type they were given a letter to denote a subtype $(1 \mathrm{a}, 1 \mathrm{~b}, 2 \mathrm{a}, 2 \mathrm{~b}$, etc.). SpeI MRPs that differed clearly from the 2 main types were assigned a separate number (3 to 8 ).

Analysis of plasmids. Isolates were grown on blood agar at room temperature for $2 \mathrm{~d}$. Plasmid DNA was isolated in accordance with the method of Grinstedt \& Bennett (1988). Plasmids were visualised in a $0.9 \%$ agarose gel (SeaKem LE, BMA) run at $4.5 \mathrm{~V} \mathrm{~cm}^{-1}$ in $40 \mathrm{mM}$ Trisacetate, $1 \mathrm{mM}$ EDTA and then stained with ethidium bromide. Plasmids from Escherichia coli Isolates V517 and 39R861 served as molecular weight markers (Macrina et al. 1978, Threlfall et al. 1986). The size of plasmids was determined by the length of migration, in accordance with the method of Rochelle et al. (1985).

\section{RESULTS}

\section{Natural AAS infection on a fish farm}

The data from Fish Farm A showed that 1 to 7 AAS outbreaks were diagnosed yearly, with an average of
3 outbreaks $\mathrm{yr}^{-1}$. An outbreak usually affected fish in several tanks, and often involved both charr and grayling at the same time. Only charr and grayling were affected, while landlocked salmon Salmo salar m. sebago, brown trout Salmo trutta m. lacustris, whitefish Coregonus lavaretus and pike-perch Stizostedion lucioperca were not. Mortality among grayling began to increase $5 \mathrm{~d}$ after the first superficial signs, whereas charr began to die without any obvious signs of the disease on their skin. Grayling developed deep skin lesions extending to muscular tissue and haemorrhage in the intestine, often accompanied by anus relapse. In charr, in contrast, haemorrhage was absent or slight in the internal organs. Outbreaks were diagnosed from mid-July to late August or early September, but 2 outbreaks were recorded in mid-October. The AAS bacteria were isolated on blood agar mainly from kidney or skin lesions, but also from the spleen, intestine, and even from the eyes of grayling in 3 cases.

Annual mortality of AAS infected fishes varied from 10 to $65 \%$ in charr stocks and from 29 to $67 \%$ in grayling stocks. Mortality did not depend on fish age. Mortality was calculated for stocks medicated by an antimicrobial drug (oxytetracycline); 20 to $40 \%$ of the stocks required 2 treatments annually.

\section{Challenge experiment}

In the challenge experiment, mortality was $90 \%$ in charr and $100 \%$ in grayling. None of the control fish died during the experiment. AAS was isolated from the gut and kidney of all moribund or dead charr and grayling. The first superficial signs of infection were visible to different degrees in both fish species 2 to $3 \mathrm{~d}$ post challenge.

Macroscopic changes in the experimentally infected charr and grayling were similar to those reported for a natural infection at Fish Farm A. In grayling, major gross pathological changes (erect scales and necrosis of the skin epithelium) were observed within $1 \mathrm{~d}$ after challenge. Thereafter, deep ulcers extending into the muscle tissue were visible. Only 5 out of 43 exposed fish did not have deep skin ulcers. Histopathological examination showed that large areas of the superficial layer of fish skin were affected (Fig. 1a). Erect scales were lost and epithelium became necrotic. Thereafter, deep ulcers developed, extending into the muscle tissue (Fig. 1a). Tissue damage in the epidermis of grayling was severe, and necrosis extended into the deep muscular fibres. No cellular defence was observed around lesions (Fig. 1a).

The disease manifested itself more slowly in charr than in grayling. Loss of scales and deep skin lesions were observed only during the second week after 

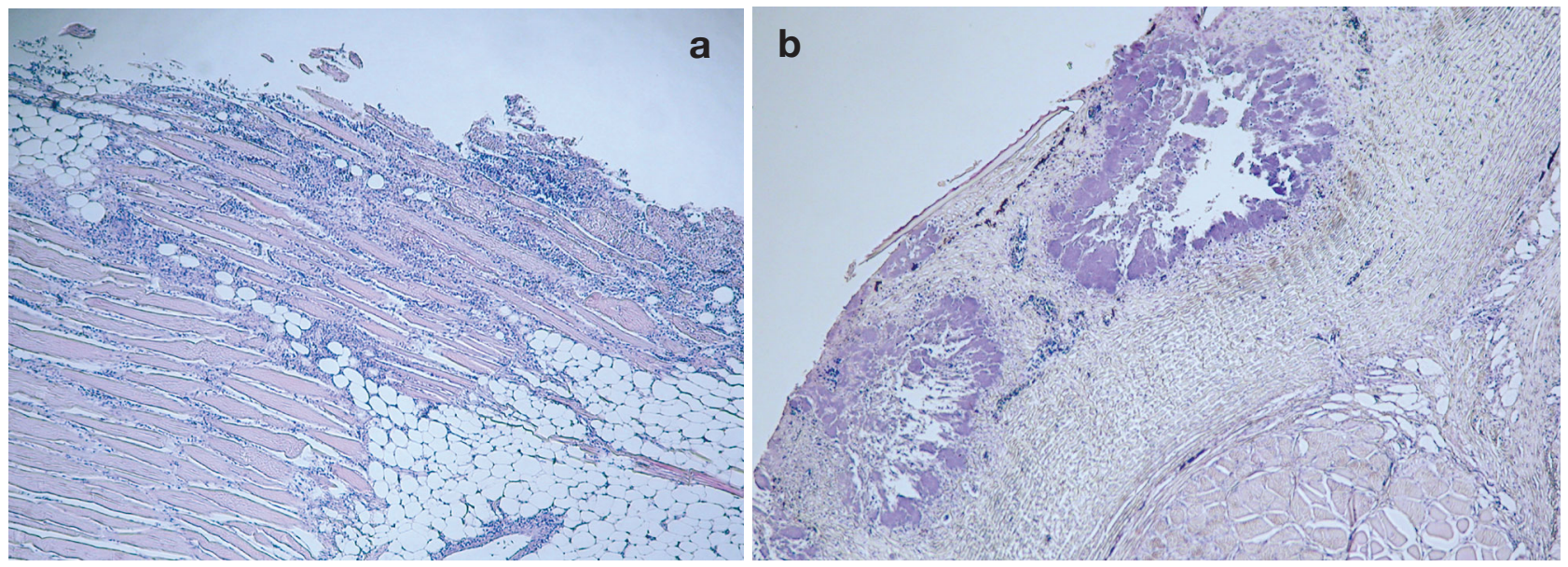

Fig. 1. (a) European grayling Thymallus thymallus; (b) Arctic charr Salvelinus alpinus. Epidermis after challenge with atypical Aeromonas salmonicida. (a) In grayling, dermis is destroyed and destruction extends to muscle; no inflammatory cell infiltration is visible. (b) In charr, necrotic tissue and bacterial colonies are surrounded by inflammatory cells in skin $(40 \times)$

challenge. Only 1 out of 20 exposed charr exhibited severe loss of scales and deep lesions typical of those found in grayling. Histopathological examination revealed thickening of the skin mucus layer and bacterial invasion of scale pockets in charr epidermis during the first few days after exposure (Fig. 1b). In the outermost layer of the epidermis, bacterial colonies surrounded by some macrophages and lymphocytic cell types were observed (Fig. 1b).

Even at later stages of infection, we could not detect any histopathological changes in the pancreas, liver, kidney or intestine of either charr or grayling. However, in the hearts of grayling sampled during the last days of the experiment, Gram-negative bacterial colonies were present in either the pericardium or aorta (not shown).

\section{Molecular genetic types of AAS}

The SpeI MRP of Finnish isolates were grouped into 2 major profiles, 1 and 2, with several subtypes (Table 1, Fig. 2). All 21 isolates from the River Vuoksi water basin belonged to the major MRP 1 group and all 15 isolates from 4 other water basins belonged to MRP 2. In Fish Farm A, the same MRP 1c was isolated from grayling in 1991 and 1992, and from charr in Fish Farm E during 1992 and 1995 (the charr in Fish Farm E originated from Fish Farm A). All Swedish isolates had unique profiles, of which $50 \%$ belonged to MRP 2 . The other $50 \%$ and the atypical pigment-producing isolate from charr from northern Finland (202) and ATCC 33659 strain had little homology with the Finnish isolates (Table1). Examples of the MRP profiles are presented in Fig. 2.

\section{Plasmid profiles}

Among the strains, 2 main plasmid profiles were seen: Profile A (with 3 subtypes), and Profile B (Table 1). Isolates from the River Vuoksi water basin from both farmed and wild fishes usually had Plasmid Profile A1 (Table 1) with 3 plasmids-17, 29 and $107 \mathrm{~kb}$ (Fig. 3); 3 isolates had an additional plasmid that was slightly larger than $107 \mathrm{~kb}$ (Profile A2), and Isolate 6 from dace Leuciscus leuciscus had an additional plasmid of $50 \mathrm{~kb}$ (Profile A3) (Fig. 3). At Fish

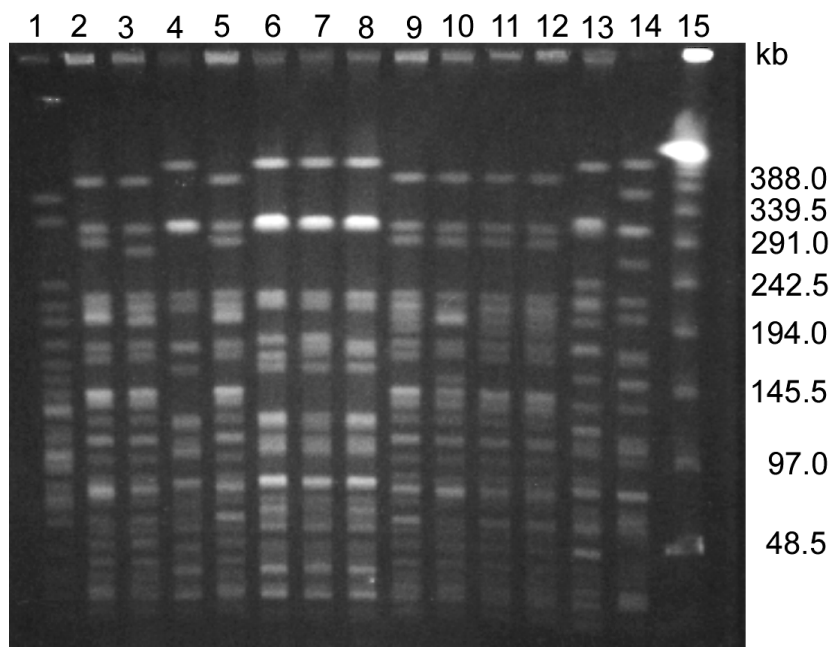

Fig. 2. Aeromonas salmonicida. SpeI macrorestriction profiles (MRP) of atypical isolates. 1: MRP 8 (ATCC 33659); 2: MRP 11, (2); 3: MRP 1m (6); 4: MRP 2k (31); 5: MRP 1o (131); 6: MRP 2f (100); 7: MRP 2c (157); 8: MRP 2b (16); 9: MRP 1b (9); 10: MRP 1g (205); 11: MRP 1h (7); 12: MRP 1h (206); 13: MRP 6 (188); 14: MRP 5 (189); 15: lambda concatemers. Numbers in parentheses are isolate nos. in Table 1 
Table 1. Aeromonas salmonicida. Atypical isolates examined in this study (Farm/Wild = isolated from farmed or wild fish, County $=$ county of isolation for Swedish strains) and their genetic characteristics. SpeI-MRP: macrorestriction profile after SpeI digestion. aspA gene results from Madetoja et al. (2003)

\begin{tabular}{|c|c|c|c|c|c|c|}
\hline Isolate & Host fish species & $\begin{array}{c}\text { Isolation } \\
\text { year }\end{array}$ & $\begin{array}{c}\text { Farm/Wild } \\
\text { County }\end{array}$ & $\begin{array}{l}\text { SpeI- } \\
\text { MRP }\end{array}$ & $\begin{array}{l}\text { Plasmid } \\
\text { type }\end{array}$ & $\operatorname{asp} \mathrm{A}$ \\
\hline \multicolumn{7}{|c|}{ Vuoksi water basin } \\
\hline 8 & Thymallus thymallus & 1989 & A & $1 \mathrm{a}$ & A1 & No \\
\hline 9 & Thymallus thymallus & 1989 & $\mathrm{~A}$ & $1 b$ & A1 & No \\
\hline 111 & Thymallus thymallus & 1991 & $\mathrm{~A}$ & $1 \mathrm{C}$ & A1 & No \\
\hline 113 & Thymallus thymallus & 1992 & $\mathrm{~A}$ & $1 \mathrm{C}$ & A1 & No \\
\hline 117 & Thymallus thymallus & 1992 & $\mathrm{~A}$ & $1 d$ & A1 & No \\
\hline 127 & Thymallus thymallus & 1993 & $\mathrm{~A}$ & $1 \mathrm{e}$ & A1 & No \\
\hline 156 & Thymallus thymallus & 1994 & A & 1f & A1 & No \\
\hline 205 & Thymallus thymallus & 1995 & $\mathrm{~A}$ & $1 \mathrm{~g}$ & $\mathrm{~A} 2$ & No \\
\hline 7 & Salvelinus alpinus & 1988 & $\mathrm{~A}$ & $1 \mathrm{~h}$ & A1 & No \\
\hline 126 & Salvelinus alpinus & 1993 & $\mathrm{~A}$ & $1 \mathrm{i}$ & A1 & No \\
\hline 154 & Salvelinus alpinus & 1994 & $\mathrm{~A}$ & 1f & A1 & No \\
\hline 206 & Salvelinus alpinus & 1995 & $\mathrm{~A}$ & $1 \mathrm{~h}$ & A1 & No \\
\hline 116 & Salvelinus alpinus & 1992 & $\mathrm{E}$ & $1 \mathrm{c}$ & A1 & No \\
\hline 203 & Salvelinus alpinus & 1995 & $\mathrm{E}$ & $1 \mathrm{C}$ & A1 & No \\
\hline 125 & Coregonus albula & 1993 & $\mathrm{~N}$ & $1 j$ & A1 & No \\
\hline 129 & Thymallus thymallus & 1993 & $\mathrm{C}$ & $1 \mathrm{k}$ & A1 & No \\
\hline 2 & Rutilus rutilus & 1988 & Wild & 11 & A1 & No \\
\hline 6 & Leuciscus leuciscus & 1988 & Wild & $1 \mathrm{~m}$ & A3 & No \\
\hline 114 & Rutilus rutilus & 1992 & Wild & 11 & A1 & No \\
\hline 130 & Rutilus rutilus & 1993 & Wild & $1 \mathrm{n}$ & A1 & No \\
\hline 131 & Rutilus rutilus & 1993 & Wild & 10 & A1 & No \\
\hline \multicolumn{7}{|c|}{ Kymijoki water basin } \\
\hline 1 & Thymallus thymallus & 1990 & $\mathrm{~B}$ & $2 \mathrm{a}$ & $\mathrm{B}$ & Yes \\
\hline 16 & Salvelinus alpinus & 1990 & $\mathrm{~B}$ & $2 b$ & B & Yes \\
\hline 118 & Thymallus thymallus & 1992 & $\mathrm{~B}$ & $2 b$ & $\mathrm{~B}$ & Yes \\
\hline 132 & Thymallus thymallus & 1993 & $\mathrm{~B}$ & $2 b$ & $\mathrm{~B}$ & Yes \\
\hline 155 & Thymallus thymallus & 1994 & $\mathrm{~B}$ & $2 \mathrm{C}$ & $\mathrm{B}$ & Yes \\
\hline 157 & Thymallus thymallus & 1995 & $\mathrm{~B}$ & $2 \mathrm{c}$ & $\mathrm{B}$ & Yes \\
\hline 201 & Thymallus thymallus & 1995 & $\mathrm{~B}$ & $2 \mathrm{C}$ & $\mathrm{B}$ & Yes \\
\hline 15 & Onchorhynchus mykiss & 1988 & $\mathrm{~K}$ & $2 d$ & $\mathrm{~B}$ & Yes \\
\hline 60 & Onchorhynchus mykiss & 1988 & M & $2 \mathrm{e}$ & $\mathrm{B}$ & Yes \\
\hline 100 & Rutilus rutilus & 1988 & Wild & $2 f$ & $\mathrm{~B}$ & Yes \\
\hline 61 & Onchorhynchus mykiss & 1988 & $\mathrm{~L}$ & $2 g$ & $\mathrm{~B}$ & Yes \\
\hline \multicolumn{7}{|c|}{ Kokemäenjoki water basin } \\
\hline 44 & Salmo trutta f. fario & 1988 & G & $2 \mathrm{~h}$ & $\mathrm{~B}$ & No \\
\hline 64 & Salmo trutta f. lacustris & 1988 & G & $2 \mathrm{i}$ & $\mathrm{B}$ & No \\
\hline \multicolumn{7}{|c|}{ Iijoki water basin } \\
\hline 26 & Salmo trutta f. trutta & 1988 & I & $2 \mathrm{j}$ & $\mathrm{B}$ & Yes \\
\hline \multicolumn{7}{|c|}{ Kemijoki water basin } \\
\hline 31 & Rutilus rutilus & 1988 & Wild & $2 \mathrm{k}$ & B & Yes \\
\hline \multicolumn{7}{|l|}{ Sweden } \\
\hline 181 & Salvelinus alpinus & 1991 & Västerbotten & 3 & $\mathrm{~B}$ & Yes \\
\hline 183 & Salvelinus alpinus & 1994 & Norrbotten & 21 & $\mathrm{~B}$ & Yes \\
\hline 186 & Salvelinus alpinus & 1988 & Värmland & 4 & $\mathrm{C}$ & No \\
\hline 189 & Salvelinus alpinus & 1992 & Gävleborg & 5 & $\mathrm{D}$ & Yes \\
\hline 196 & Salvelinus alpinus & 1985 & Jämtland & $2 \mathrm{~m}$ & $\mathrm{E}$ & Yes \\
\hline 184 & Salvelinus fontinalis & 1986 & Södermanland & $2 n$ & $\mathrm{~B}$ & Yes \\
\hline 188 & Thymallus thymallus & 1994 & Kopparberg & 6 & $\mathrm{~F}$ & No \\
\hline 195 & Thymallus thymallus & 1985 & Jämtland & 20 & $\mathrm{E}$ & Yes \\
\hline \multicolumn{7}{|c|}{ Pigment-producing atypical isolates } \\
\hline 202 & Salvelinus alpinus (Finland) & 1995 & F (Inari basin) & 7 & G & No \\
\hline ATCC 33659 & Salmo trutta (reference strain) & & & 8 & $\mathrm{H}$ & Yes \\
\hline
\end{tabular}




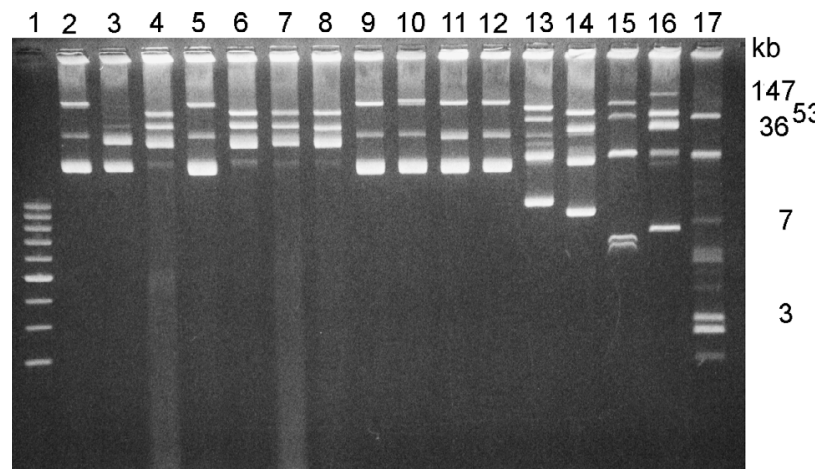

Fig. 3. Aeromonas salmonicida. Plasmid profiles of atypical isolates. 1: supercoiled DNA; 2: profile A2 (2); 3: profile A3 (6); 4: profile B $(31) ; 5$ : profile A1 (131); 6 : profile B $(100) ; 7$ : profile B (157); 8: profile B (16); 9: profile A1 (9); 10: profile A2 (205); 11: profile A1 (7); 12: profile A1 (206); 13: profile F (188); 14 : profile D (189); 15: profile H (ATCC 33659); 16: Escherichia coli 39R861; 17: E. coli V517. Numbers in parentheses are isolate nos. in Table 1

Farm A, the same plasmid profile (A1) prevailed from 1989 to 1995 (Table 1). Isolates from other water basins belonged to the other main profile (B) with plasmids of 26, 46 and $87 \mathrm{~kb}$ (Fig. 3); 3 Swedish isolates belonged to this plasmid group (Strain Nos. 181, 183 and 184) (Table 1). Plasmid Profile A with its 3 subtypes was associated with SpeI MRP 1, and Profile B with MRP 2 (Table 1). All Finnish and 2 out of 4 Swedish AAS isolates of MRP 2 had the identical plasmid profile, B. Plasmids of $10 \mathrm{~kb}$ or less were only observed in pigment-producing AAS Isolate 202, Strain ATCC 33569, and 5 of the Swedish isolates.

\section{DISCUSSION}

The present study has characterised the disease caused by atypical Aeromonas salmonicida infection in charr and grayling. Under farming conditions, we observed different signs and the clinical course of AAS disease in both species. Molecular genetic typing of isolates from charr and grayling revealed that genetically identical strains infected both fish species in Fish Farm A, suggesting that differences in pathology arose from fish host factors. By using a single AAS strain in challenges, the signs and pathology observed in both fish species under farming conditions could be reproduced in an experimental infection. Thus, we concluded that host factors, or interactions between the host and the bacterium, are responsible for the different clinical course of the AAS infection in charr and grayling.

AAS bacteria are widely spread in inland water systems in Finland (Hänninen \& Hirvelä-Koski 1997, 1999, Madetoja et al. 2003). Bacteria have been isolated occasionally from diseased fish of various spe- cies, such as roach Rutilus rutilus, vendace Coregonus albula and dace (Madetoja et al. 2003); from cyprinid fishes and the flounder Platichthys flesus in the Archipelago area of the Baltic Sea (Wiklund et al. 1999); and from brown trout in the River Kymijoki and Oulujoki water basins (Rintamäki \& Valtonen 1991). Isolates from these fish species were also analysed in the present study. According to genetic profiles, the isolates from various fish species, including charr and grayling, were genetically identical within either one water basin, but disparate between the River Vuoksi and Kymi water basins. The wide spread and eventual multiplication of AAS strains in various fish species pose a specific threat to charr and grayling farms, since inland water systems are contaminated with achromogenic AAS that are pathogenic to charr and grayling.

Data from Fish Farm A and from other field cases indicated that under farm conditions, charr and grayling are exceptionally susceptible to AAS infection. On Fish Farm A, charr and grayling were reared together with other salmonid fishes-landlocked salmon, whitefish, and brown trout. During the $8 \mathrm{yr}$ follow-up period and thereafter, AAS outbreaks have never occurred among other salmonid fishes in Fish Farm A, nor have AAS bacteria been isolated from any species other than charr and grayling. The same applies to Fish Farm B in the River Kymijoki water basin, where AAS bacteria were isolated only from grayling, not from other salmonids (P. Pylkkö et al. unpubl.). Charr were occasionally reared on this farm. Although we did not study experimentally the susceptibility of various fish species to infection, we conclude that, under farming conditions, charr and grayling are particularly susceptible to achromogenic AAS infection.

To our knowledge, this is the first time experimental AAS infection has been described in charr. Carlstein (1996) described experimental AAS infection in grayling, but no histopathological studies were made. According to our study, the gross signs of AAS infection in grayling and charr are evident on the skin. Grayling had wide haemorrhagic skin ulcers that sometimes extended into the musculature, whereas the ulcers were smaller, often pinpoint, and more superficial in charr. Histological examination revealed some macrophages and mononuclear cells around bacterial colonies and necrotic tissue in charr epidermis, whereas no inflammatory reaction was evident in the skin of grayling. Massive bacterial colonies were visible in the pericardium of graylings in the later stages of infection. In both species, AAS bacteria were isolated from the kidney, gut and skin ulcerations after experimental challenge.

AAS infection in non-salmonids has most often been described as a skin infection without subsequent septi- 
caemia. Carp erythodermatitis, goldfish ulcer disease, and ulcer disease of flounder in the Baltic Sea and Northern Sea are the best described diseases in this category. Histopathology often comprises mononuclear inflammatory cells around the ulcers (Wiklund \& Dalsgaard 1998). In salmonids the pathology is not well described. Rintamäki \& Valtonen (1991) stated that the gross pathological signs of achromogenic AAS infection in salmon, brown trout and sea trout Salmo trutta m. trutta differed markedly from the signs of infection caused by either typical AS or pigment-producing AAS in the same species. Shallow lateral ulcers on the skin were typical in achromogenic AAS infection, and often no other macroscopic changes were observed. The gross signs for furunculosis and for pigment-producing AAS infection were similar: fin base haemorrhage and erosion and sometimes small furuncles. Carlstein (1996) described gross signs of natural and experimental achromogenic AAS infection in grayling. In natural infection, 0+-stage grayling had skin haemorrhage and ulceration. The infection could be reproduced experimentally by bathing grayling fingerlings in water containing $10^{8}$ bacteria $\mathrm{ml}^{-1}$ (Carlstein 1996). The challenged fish developed skin haemorrhage and some had cloudy and partly eroded cornea. Boomker et al. (1984) described skin ulceration in rainbow trout infected with AAS, but few gross changes were visible in internal organs. When evident, the changes included slight enlargement of spleen and kidney and discolouration of the liver. Cellular infiltration and considerable tissue destruction were seen in ulcers by light microscopy. The spleen and liver were congested, and in the kidney slight vasculitis and degeneration of tubular epithelium were encountered. Bacterial colonies were present only in the sections of skin (Boomker et al. 1984).

Genetically, using SpeI MRP and plasmid analysis, the isolates were divided into 2 major genotypes. Within the main genotypes the differences between isolates were due to 1 to 7 band differences in SpeI MRP. The band differences between SpeI MRP 1 and MRP 2 were based on heavy bands of approximately 280 to $430 \mathrm{~kb}$. Thus the plasmids, which were all $<150 \mathrm{~kb}$, did not define the major MRPs. Compared with the Finnish achromogenic AAS isolates, the Swedish strains showed greater heterogeneity with respect to SpeI MRPs and plasmid types. There was no relationship between fish species and genotypes, with the same major genotypes found in farmed salmonids and wild fishes. The isolates from grayling and charr did not have any specific genotypes, and thus the vulnerability of these species to achromogenic AAS infection was not explained by a specific genotype. In Fish Farms A and B, where AAS bacteria have occurred over many years in grayling and charr, the genotypes have remained fairly homogenous. Hänninen \& Hirvelä-Koski (1999) have previously shown that certain genotypes of achromogenic AAS are strongly associated with Arctic charr and grayling. Our genotype studies confirm their observation that these species are infected with 2 homogenous groups of strains, and that these genotypes have persisted over years.

Lake Saimaa in the River Vuoksi water basin, SE Finland, was formed after the last glacial period 10000 yr ago, and several salmonid species became isolated from the sea in this process. Charr and grayling and some other salmonid species survived in the area. These species represent genetically valuable and endangered stocks that require restocking in order to sustain population numbers. To preserve genetic background, offspring must be released in the same water basin in which the broodstock fish originated. This could partly explain how a particular major genotype of AAS, MRP 1, Plasmid Profile A and genome without the aspA gene, has been detected in the fish farms of the River Vuoksi water basin over a long period (Table 1).

Recently, Gudmundsdóttir et al. (2003) grouped AAS and typical AS strains according to the production of the known Aeromonas salmonicida exotoxins P1, GCAT, AsaP1 and a newly described serine caseinase different from P1; 3 Finnish AAS isolates from salmonid fish, including Strains 9 and 121 from the same outbreak as Strain 125 in the present study, were analysed. The Finnish strains belonged to the group of AAS strains that did not produce any known exotoxin. The results are in accordance with our finding that excreted toxins do not seem to play a major role in the pathogenesis of AAS infection in charr and grayling (Madetoja et al. 2003). All Finnish strains possessed satA gene for GCAT, but apparently it was not expressed, at least in vitro (Madetoja et al. 2003). The same applied to the production of P1 serine protease in strains possessing aspA gene (Madetoja et al. 2003). The finding that a major group of strains in the MRP 1 completely lack aspA further indicates that at least P1 is not essential for virulence in charr and grayling. The non-toxic group observed by Gudmundsdóttir et al. (2003) also included A. salmonicida subsp. masoucida isolates. O'hIci et al. (2000) analysed genetic diversity of A. salmonicida by PFGE; 3 AAS isolates from brown trout in Finland showed a $75 \%$ PFGE-based similarity to the type subsp. masoucida. However, when Lund et al. (2002) used amplified fragment length polymorphism to determine genetic diversity, the 2 strains from Fish Farms A and B of this study did not cluster with subsp. masoucida. They clustered close to 2 Norwegian AAS strains, 1 of which was from charr. Clearly, further studies are needed to classify the achromogenic AAS isolates from charr and grayling. 
An inadequate understanding of the virulence mechanisms of AAS infection of charr and grayling has hampered the development of efficient vaccines. In Iceland, where AAS infection is endemic, with mortality comprising up to $30 \%$ of total Atlantic salmon production, the use of exotoxin-based vaccine has been effective (Gudmundsdóttir 1997, Gudmundsdóttir \& Gudmundsdóttir 1997, Gudmundsdóttir \& Magnadóttir 1997). So far, we can conclude from the similarities between the AAS isolates from charr and grayling that 1 AAS strain could be used to develop a vaccine effective in both species.

Acknowledgements. This study was supported financially by the Nordic Council of Ministers under project number 66080400 . We thank our colleagues at the Swedish Veterinary Institute (SVA), Uppsala, Sweden, for the Swedish AAS strains. We are grateful to R. Liimatainen and T. Kortelainen for skilful laboratory assistance. Professor T. Valtonen is thanked for critical reading of the manuscript.

\section{LITERATURE CITED}

Austin B, Austin DA (1993) Aeromonadaceae representatives (Aeromonas salmonicida). In: Laird LM (ed) Bacterial fish pathogens: diseases in farmed and wild fish, 2nd edn. Ellis Horwood, London, p 86-170

Austin B, Austin DA, Dalsgaard I, Gudmundsdóttir BK and 5 others (1998) Characterization of atypical Aeromonas salmonicida by different methods. Syst Appl Microbiol 21:50-64

Boomker J, Henton MM, Naudé TW, Huchzermeyer FW (1984) Furunculosis in rainbow trout (Salmo gairdneri) raised in sea water. Onderstepoort J Vet Res 51:91-94

Carlstein M (1996) Feeding, growth and survival of European grayling in culture and after stocking. $\mathrm{PhD}$ dissertation, Swedish University of Agricultural Sciences, Umeå

Grinsted J, Bennett PM (1988) Preparation and electrophoresis of plasmid DNA. Methods Microbiol 21:129-153

Gudmundsdóttir BK (1997) Aeromonas salmonicida subsp. achromogenes-a study of extracellular virulence factors and immunity in Atlantic salmon (Salmo salar L.). PhD dissertation, University of Iceland, Reykjavic

Gudmundsdóttir BK, Gudmundsdóttir S (1997) Evaluation of cross protection by vaccines against atypical and typical furunculosis in Atlantic salmon, Salmo salar L. J Fish Dis $20: 343-350$

Gudmundsdóttir BK, Magnadóttir B (1997) Protection of Atlantic salmon (Salmo salar L.) against an experimental infection of Aeromonas salmonicida ssp achromogenes.

Editorial responsibility: David Bruno,

Aberdeen, UK
Fish Shellfish Immunol 7:55-69

Gudmundsdóttir BK, Hvanndal I, Bjornsdóttir B, Wagner U (2003) Analysis of exotoxins produced by atypical isolates of Aeromonas salmonicida, by enzymatic and serological methods. J Fish Dis 26:15-29

Hänninen ML, Hirvelä-Koski V (1997) Molecular and phenotypic methods for characterisation of atypical Aeromonas salmonicida. Vet Microbiol 56:147-158

Hänninen ML, Hirvelä-Koski V (1999) Genetic diversity of atypical Aeromonas salmonicida studied by pulsed-field gel electrophoresis. Epidemiol Infect 123:299-307

Holt JG, Krieg NR, Sneath PHA, Stanley JT, Williams ST (eds) (1994) Group 5 facultatively anaerobic Gram-negative rods subgroup 2: family Vibrionaceae. In: Bergey's manual of determinative bacteriology, 9th edn. Williams \& Wilkins, London, p 175-290

Lund V, Jenssen LM, Wesmajervi MS (2002) Assessment of genetic variability and relatedness among atypical Aeromonas salmonicida from marine fishes, using AFLPfingerprinting. Dis Aquat Org 50:119-126

Macrina FL, Kopecko DJ, Jones KR, Mayers DJ, McCowan SM (1978) A multiple plasmid-containing Escherichia coli strain: convenient source of size reference plasmid molecules. Plasmid 1:417-420

Madetoja J, Pylkkö P, Pohjanvirta T, Schildt L, Pelkonen S (2003) Putative virulence factors of atypical Aeromonas salmonicida isolated from Arctic charr, Salvelinus alpinus (L.), and European grayling, Thymallus thymallus (L.). J Fish Dis 26:349-360

O'hIci B, Olivier G, Powell R (2000) Genetic diversity of the fish pathogen Aeromonas salmonicida demonstrated by random amplified polymorphic DNA and pulsed-field gel electrophoresis analyses. Dis Aquat Org 39:109-119

Pavan ME, Abbott SL, Zorzópulos J, Janda JM (2000) Aeromonas salmonicida subsp. pectinolytica subsp nov., a new pectinase-positive subspecies isolated from a heavily polluted river. Int J Syst Evol Microbiol 50:1119-1124

Rintamäki P, Valtonen ET (1991) Aeromonas salmonicida in Finland: pathological problems associated with atypical and typical strains. J Fish Dis 14:323-333

Rochelle PA, Fry JC, Day MJ, Bale MJ (1985) An accurate method for estimating sizes of small and large plasmids and DNA fragments by gel electrophoresis. J Gen Microbiol 132:53-59

Threlfall EJ, Rowe B, Ferguson JL, Ward LR (1986) Characterization of plasmids conferring resistance to gentamycin and apramycin in strains of Salmonella typhimurium phage type 204c isolated in Britain. J Hyg 97:419-426

Wiklund T, Dalsgaard I (1998) Occurrence and significance of atypical Aeromonas salmonicida in non-salmonid and salmonid fish species: a review. Dis Aquat Org 32:49-69

Wiklund T, Tabolina I, Bezgachina TV (1999) Recovery of atypical Aeromonas salmonicida from ulcerated fish from Baltic Sea. ICES J Mar Sci 56:175-179

Submitted: July 19, 2004; Accepted: February 22, 2005 Proofs received from author(s): August 15, 2005 